\title{
Horse Ranching Increases Biodiversity in a Foothills Parkland Prairie in Northern Kananaskis Country, Western Alberta
}

\author{
Paul M. Catling ${ }^{1,3}$, Brenda Kostiuk ${ }^{1}$, and Don Thompson ${ }^{2}$ \\ ${ }^{1}$ Agriculture and Agri-Food Canada, Environmental Health, Biodiversity, William Saunders Building, Central Experimental \\ Farm, Ottawa, Ontario K1A 0C6 Canada \\ ${ }^{2}$ Agriculture and Agri-Food Canada, Lethbridge Research Centre, 54031 Avenue South, P.O. Box 3000, Lethbridge, Alberta \\ T1J 4B1 Canada \\ ${ }^{3}$ Corresponding author: catlingp@agr.gc.ca
}

Catling, Paul M., Brenda Kostiuk, and Don Thompson. 2015. Horse ranching increases biodiversity in a foothills parkland prairie in northern Kananaskis Country, western Alberta. Canadian Field-Naturalist 129(1): 15-23.

\begin{abstract}
Vascular plant biodiversity was evaluated in two adjacent sections of a continuous prairie glade. One section has been subject to moderate grazing by feral horses (Equus ferus caballus) in late summer and fall for the past 25 years, while the other has been protected. From 28 June to 2 July 2009, we recorded cover for all vascular plants present in ten $1-\mathrm{m}^{2}$ quadrats along five transects in each section. We calculated biodiversity measures, including species richness, evenness, and ShannonWiener and Simpson's diversity indexes. Horse grazing did not affect richness but significantly increased evenness. Grazing increased the Shannon-Wiener index, but did not affect the Simpson's index. Cover and frequency values for most species differed significantly between the two sites. Mountain Rough Fescue (Festuca campestris Rydberg) dominated the nongrazed site but several shorter grasses and different forbs dominated the grazed site. The plant community in the grazed areas can be seen as an earlier seral stage of the fescue community with a different contingent of plant species. Light grazing in part of the prairie glade increased overall plant diversity so that it provided more diverse animal habitat.
\end{abstract}

Key Words: Horses; Feral Horse; Equus ferus caballus; Mountain Rough Fescue; Festuca campestris; grazing; rangeland; vascular plants; biodiversity; richness; heterogeneity; eveness; Alberta; prairie foothills; Kananaskis; fescue grassland; shifting mosaic; patch dynamics; management

\section{Introduction}

A huge ecological cost is associated with livestock grazing in western North America, and continuing interest from conservation biologists is essential to ensure that management protects biodiversity (Fleischner 1994). The extensive literature on maintenance of healthy rangeland for livestock production in western Canada has led to an understanding that many rangeland species may benefit from moderate grazing (e.g., Tannas 2003a,b, 2004). However, the effects of grazing on biodiversity overall have not been sufficiently studied in Canada (Ollf and Ritchie 1998; Bai et al. 2001), although some important research is underway (e.g., the long-term east block grazing experiment in Grasslands National Park, see http://www.pc.gc.ca/eng /progs/np-pn/re-er/ec-cs/ec-cs01.aspx). Research to date has involved mostly cattle on the prairies and parklands and suggests that rangelands can be important in protecting biodiversity, although ecological integrity cannot be maintained if grazing pressure is too high (Trottier 1993; West 1993; McLaughlin and Mineau 1995).

The grazing ecology of the prairies of the Rocky Mountain foothills has been poorly studied, although they are the most diverse and complex of the fescue grasslands in Canada (Tannas 2003a, P.M.C. personal observation) and among the most productive grasslands in North America (Willms et al. 1996). The response of fescue grasslands to cattle stocking rates has been studied intensively at one site in the Porcupine Hills near
Stavely, Alberta (Willms et al. 1985), but this site may not represent the foothills grasslands well. Only $5 \%$ of the grasslands remain in a pre-settlement condition (Vujnovic 1998), and they are now recognized as an endangered ecosystem (Trottier 2002). Increased precipitation in foothills prairies may make them more susceptible to grazing (Lauenroth et al. 1994).

There are currently over 350000 feral horses (Equus ferus caballus) in Alberta, mostly used in recreation, and the number is increasing (Westar 2003*). Consequently, the demands for grazing land are also increasing, particularly in the foothills region. Grazing by horses has been shown to reduce plant species richness in some situations (Beever and Brussard 2000; Beever et al. 2008), but not in others (Detling 1998). These differences are likely a result of different grazing pressures.

With the effects of grazing generally requiring more study, especially in the foothills, and especially concerning feral horses, any situation providing data is an important study opportunity. We encountered such an opportunity in a foothills parkland prairie in northern Kananaskis Country of western Alberta. Here feral horses had been excluded for 25 years from half of a continuous fescue prairie glade, but rest-rotation grazing at a specific carrying capacity was continued in the adjacent half. Data was collected to elucidate the effects of grazing by the horses on floristic diversity, as well as to obtain information for conservation and management. 


\section{Study Area}

The area studied was within the Kananaskis Country in Bow Valley Provincial Park, at $51.0789^{\circ} \mathrm{N}$ and $115.0384^{\circ} \mathrm{W}$. It consisted of a 5-ha prairie glade separated into two parts by a $10-\mathrm{m}$ wide road allowance. The glade was surrounded by a semi-open woodland that included Trembling Aspen (Populus tremuloides Michaux), Lodgepole Pine (Pinus contorta var. latifolia Engelmann), Douglas Fir (Pseudotsuga menziesii var. glauca [Beissner] Franco), and White Spruce (Picea glauca [Moench] Voss). The park is a significant natural area with a rich diversity of flora and fauna (Pinel 1985*; Wallis and Wershler 1972*; Williams 1988*).

\section{Requirements for comparison}

To be able to attribute differences in vascular plant composition between the two sections to differences in grazing by feral horses, all other characteristics should be nearly the same. There is good evidence that this was the case. The two sections, "grazed" and "non-grazed," had similar gradual slopes, elevation, and very stony substrates, and the geology of the area was uniform (Rutherford 1927; Greenlee 1974; P.M.C. personal observation). The sections were separated only by a road and roadside fences, which clearly split a formerly continuous prairie glade, the edges of which remained well defined.

The entire glade was grazed by feral horses until 1984 (G. Cowley, Rafter Six guest ranch, personal communication) when grazing was discontinued on the south side (2.2 ha). On the north side (2.8 ha), grazing by horses was permitted at a moderate stocking level in the fall (15 August to 15 October) for 652 horse-days on approximately 22 ha of prairie which included the north half of the glade as well as open woods and other glades nearby. Over this period, both halves were subject to very light grazing by free-ranging Rocky Mountain Elk (Cervus elaphus nelsoni) and grazing to an even lesser extent by both Mule Deer (Odocoileus hemionus) and White-tailed Deer (Odocoileus virginianus) (R. Jaeger, park conservation officer, personal communication). The Rocky Mountain Elk ( $n=100$ 160) also used the area from December to February as one of a large series of openings preferred because characteristic high wind and chinooks reduce snow accumulation and adjacent wooded areas provide cover (R. Jaeger, personal communication). Other grazing mammals, including various rodents, are scarce in this area of gravelly soils and are thought to have little impact on flora (P.M.C., personal observation).

\section{Methods}

\section{Data collection and identification}

Between 28 June and 2 July 2009, in each section (grazed and non-grazed), data on the presence and cover of species were gathered from $1-\mathrm{m}^{2}$ quadrats along five parallel transects at a $45^{\circ}$ angle from the road. Ten quadrats, each $10 \mathrm{~m}$ apart, were placed on each transect, resulting in 50 quadrats on either side of the road (i.e., in each section). Cover for each species in each quadrat was estimated as a percentage of the $1-\mathrm{m}^{2}$ ground surface covered by living material of that species. The results were tallied so that species in the two sections could be compared with respect to both frequency and cover. No new species were recorded after 35 quadrats in either section suggesting that 50 was an adequate sample to describe the vegetation.

As grazing may sometimes result in more-or-less stable, heavily grazed and non-grazed patches, and increased heterogeneity may exist on a broad scale but not on a small scale (Willms et al. 1988), a relatively extensive sampling procedure, such as that used here, is advantageous in biodiversity comparison.

Most species were flowering at the time of sampling, and this aided in identification; the few exceptions were Gentianella amarella, Solidago simplex ssp., and Symphyotrichum laeve var. geyeri. Plants were identified using Packer (1994), Kuijt (1982), Hallworth and Chinappa (1997), and Tannas (2003a,b, 2004) as well as the online Flora of North America series (1993-2009).

The names mostly follow the recent compilation of Kartesz and Meachum (1999*) with some more recent changes from Brouillet et al. (2010+*). All species recorded in the prairie glade are listed in Appendix Table 1 with authorities, scientific names and frequently used common names. Voucher specimens are preserved in the National Collection of Vascular Plants of Agriculture and Agri-Food Canada in Ottawa (acronym DAO). Although the identifications are considered accurate, there were limitations. Some species were too immature to identify with certainty to the infraspecific level (e.g., Solidago simplex).

The dominant grass in the non-grazed area appeared to be Festuca campestris Rydberg, but this could be confirmed in only a few quadrats where it was flowering. As we believed that only one species of the rough fescue complex was present, all non-flowering plants were assumed to be this species. The site is near the boundary of the ranges of Fesctuca campestris and F. altaica. Kananaskis is located at $51^{\circ} \mathrm{N}$, very close to the southern limit of $F$. altaica in the Canadian Cordillera (Pavlick and Looman 1984). Bowden (1960) determined that the chromosome number of rough fescue plants at other sites near Banff, Alberta, was $2 n=56$, which is characteristic of $F$. campestris (F. altaica is reported with $2 \mathrm{n}=28$ ). However, we observed some plants with characteristics of $F$. altaica but nevertheless best placed with $F$. campestris.

\section{Data analysis}

Mean cover (including zeros) for each species was calculated for each of the five, 10-quadrat transects for each grazing treatment. Frequency was the percentage of the 10 quadrats in a transect that contained that species. Covers and frequencies of each species were compared with a Proc T-test using the five transects as replicates. This test was generated with SAS software (SAS $\left.2003^{*}\right)$. The summary function of PC-Ord 
TABLE 1. Mean cover and frequency of the more abundant ( $\geq 1 \%$ mean cover in either group) of 91 species in adjacent sections of prairie either grazed or non-grazed by Feral Horses (Equus ferus caballus), northern Kananaskis Country, Alberta.

\begin{tabular}{|c|c|c|c|c|}
\hline \multirow[b]{2}{*}{ Species } & \multicolumn{2}{|c|}{ Cover $(\%)$} & \multicolumn{2}{|c|}{ Frequency $(\%)$} \\
\hline & Grazed & $\overline{\text { Non-grazed }}$ & Grazed & $\overline{\text { Non-grazed }}$ \\
\hline \multicolumn{5}{|l|}{ Grasses and sedges } \\
\hline Carex obtusata & $4.14 *$ & $0.32 *$ & $76^{*}$ & $12 *$ \\
\hline Elymus lanceolatus & $9.48 *$ & $3.06^{*}$ & $76^{*}$ & $30 *$ \\
\hline Festuca campestris & $0.42 *$ & $30.26^{*}$ & $48 *$ & $98 *$ \\
\hline Koeleria macrantha & $8.24 *$ & $1.78^{*}$ & $88 *$ & $48 *$ \\
\hline Muhlenbergia richardsonis & $0.26^{*}$ & $3.36^{*}$ & $6^{*}$ & $26^{*}$ \\
\hline Poa secunda & $5.32 *$ & $0.72 *$ & $84 *$ & $22 *$ \\
\hline \multicolumn{5}{|l|}{ Forbs } \\
\hline Anemone multifida & $0.16^{*}$ & $1.08^{*}$ & $8 *$ & $40 *$ \\
\hline Antennaria parvifolia & $2.64 *$ & $0.26^{*}$ & $40 *$ & $8^{*}$ \\
\hline Artemisia frigida & $3.34 *$ & $0.04 *$ & $56 *$ & $2 *$ \\
\hline Anticlea elegans & $2.20 *$ & $0.066^{*}$ & $56^{*}$ & $28 *$ \\
\hline Campanula rotundifolia & 2.28 & 1.14 & $52 *$ & $40 *$ \\
\hline Cerastium arvense & $3.76^{*}$ & $1.90 *$ & $94 *$ & $60 *$ \\
\hline Comandra umbellata & $1.40^{*}$ & $0.30 *$ & $36 *$ & $14 *$ \\
\hline Erigeron caespitosus & $1.48^{*}$ & $0.16^{*}$ & $44 *$ & $6^{*}$ \\
\hline Galium boreale & 3.98 & 4.36 & 90 & 82 \\
\hline Geum triflorum & $0.06^{*}$ & $2.24 *$ & $22 *$ & $52 *$ \\
\hline Hedysarum boreale & 0.84 & 1.26 & $2 *$ & $18 *$ \\
\hline Oxytropis monticola & $4.60 *$ & $1.36^{*}$ & $68 *$ & $46^{*}$ \\
\hline Oxytropis sericea & $2.62 *$ & $0.06^{*}$ & $58 *$ & $8^{*}$ \\
\hline Potentilla concinna & 1.02 & 0.46 & 28 & 22 \\
\hline Primula conjugens & $0.16^{*}$ & $1.00 *$ & $10 *$ & $42 *$ \\
\hline Pulsatilla patens & $2.66^{*}$ & $0.98^{*}$ & 58 & 46 \\
\hline Toxicoscordion venenosus & $1.92 *$ & $0.06^{*}$ & $52 *$ & $4 *$ \\
\hline Vicia americana & $0.08 *$ & $1.94 *$ & $2 *$ & $40 *$ \\
\hline \multicolumn{5}{|l|}{ Shrubs } \\
\hline Arctostaphylos uva-ursi & $0.80 *$ & $14.84 *$ & $10 *$ & $42 *$ \\
\hline Dasiphora fruticosa & $0.40 *$ & $1.82 *$ & 6 & 16 \\
\hline Juniperus horizontalis & 15.46 & 14.46 & 46 & 52 \\
\hline \multicolumn{5}{|l|}{ Other } \\
\hline Selaginella densa & $7.54 *$ & $1.04 *$ & $68 *$ & $18 *$ \\
\hline
\end{tabular}

*Significant difference between grazed and non-grazed sections $(P<0.05$, Student's $t$ test).

(McCune and Grace 2002*) was used to determine the two components of diversity (species richness and evenness) as well as two indices of diversity (Shannon-Wiener and Simpson's indexes) for each transect using mean species covers. The diversity variables were compared between grazing treatments (Proc T-TEST of SAS) using the results for the five transects as replicates.

\section{Results}

A total of 91 species were recorded in the 100 quadrats and 96 species (not including surrounding trees) were recorded in the entire prairie glade including the quadrats. The full species list is presented in Appendix I (along with authorities, common names and the accession numbers of voucher specimens at DAO). There were only five introduced species, and these were present in trace amounts.

The plant communities in grazed and non-grazed areas appeared different (Figure 1). The mean cover and mean frequency of species with a cover of at least $1 \%$ are listed in Table 1 by major group. There was consid- erable divergence in the species composition between the grazed and non-grazed sites. Festuca campestris and Arctostaphylos uva-ursi dominated the non-grazed site where covers were much greater than in the grazed site $(30.26 \%$ versus $0.42 \%$ and $14.84 \%$ versus $0.8 \%$, respectively). Other species with greater cover in the non-grazed areas included Mulhenbergia richardsonis, Geum triflorum, Vicia americana, and Dasiphora fruiti$\cos a$.

With grazing, the cover of many species increased. Among the graminoids, Carex obstusata, Elymus lanceolatus ssp. lanceolatus, Koeleria macrantha, and Poa secunda ssp. secunda increased. Among the forbs Anemone patens var. multifida, Antennaria parvifolia, Anticlea elegans, Artemisia frigida, Cerastium arvense, Oxytropis monticola, O. sericea, and Toxicoscordion venosum var. venenosum were more abundant in the grazed sites. Selaginella densa increased considerably with grazing. Several species including Astragalus laxmannii var. robustior, Galium boreale, Potentilla concinna, and Juniperus horizontalis had similar covers 

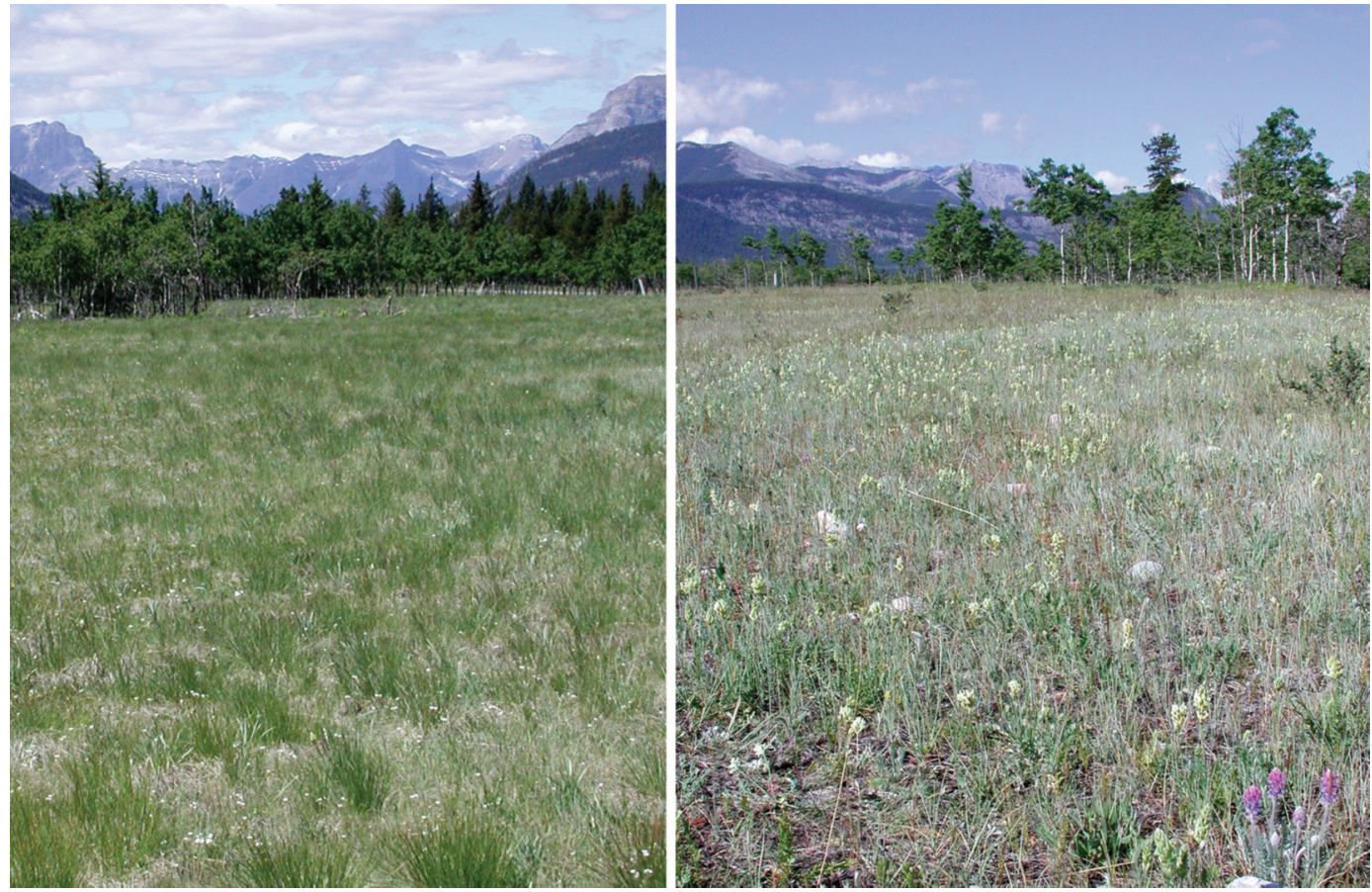

FIGURE 1. Area in northern Kananaskis Country, Alberta, non-grazed by Horses (Equus ferus caballus) (left) showing clumps of Festuca campestris Rydberg and grazed area (right) showing more abundant wildflowers, including, in particular, the yellow-flowered species of Oxytropis, $O$. monticola and $O$. sericea). The blue-green colour of the prairie on the right is a result of more open-ground and pale plants such as Artemisia frigida and Elymus lanceolatus. Although still present as scattered culms, clumps of Festuca campestris are absent from the photo on the right. Photo by Paul M. Catling.

in both grazing treatments.

The mean number of species (species richness) did not differ between the grazing treatments (Table 2). Evenness was significantly greater with horse grazing. The Shannon-Wiener index indicated that feral horse grazing increased the species diversity of the plant community, whereas Simpson's index showed no effect.

TABLE 2. Effect of Feral Horse (Equus ferus caballus) grazing on mean diversity components determined from species covers in northern Kananaskis Country, Alberta.

\begin{tabular}{lcc}
\hline \hline & Grazed & Not grazed \\
\hline Species number & 44.6 & 48.8 \\
Evenness & $0.802^{*}$ & $0.685^{*}$ \\
Shannon-Wiener index & $3.041^{*}$ & $2.661^{*}$ \\
Simpson's index & 0.805 & 0.849 \\
\hline \hline
\end{tabular}

*Significant difference between grazed and not-grazed section $(P<0.05$, Student's $t$ test $)$.

\section{Discussion}

Our list (Appendix 1) contains many species that have been observed in the various seral stages of the $F$. campestris grassland at the Stavely site in the Porcupine hills of southern Alberta (Willms et al. 1985). On the other hand, some species common in that grassland were either not present or were present in only trace amounts, including Danthonia parryi Scribner and F. idahoensis Elmer. Our site is at the northern limit of the former and beyond the northern limit of the latter (Packer 1994).

The low abundance of introduced species (5 of 94 in Appendix 1) suggests that, even with grazing, this is a relatively pristine plant community. Most important, only trace amounts of Poa pratensis L., one of the main species seen to increase with grazing at many F. campestris sites, were found here. Greater evenness with grazing reflects the great reduction in F. campestris and Arctostaphylous uva-ursi cover that favours a diversity of other species. Rough Fescue is known to be grazing sensitive (Willms et al. 1985), but why A. uva-ursi declines is not clear, as it is seldom grazed by horses. Trampling may be a factor.

Many of the species that increased with grazing have a more prostrate growth form and, thus, may partly avoid grazing. With grazing, four graminoids increased at the expense of $F$. campestris. The "increasers" did not include Danthonia parryi, which was the main increaser at the Stavely site (Willms et al. 1985). The cover of many of the lower growing forbs was also greater at the grazed site, including Antennaria parvifolia, Anticlea elegans, 
Artemisia frigida, Cerastium arvense, Oxytropis spp., and Toxicoscordion venenosum var. venenosum. Two palatable legumes (Hedysarum boreale and Vicia americana) increased with protection from grazing. Because of their high nutritive value, these are likely favoured by horses.

A short stature helps some species tolerate grazing, but makes them more susceptible to competition from robust grasses like Festuca campestris; thus, they would be expected to decline with protection from grazing. Competitive exclusion occurs when removal of disturbances, such as livestock grazing, allows a highly competitive species such as $F$. campestris to restrict the growth of other species through rapid canopy and root development, which limit both light and moisture availability, and litter accumulation, which reduces recruitment from tillers or seed (Grime 1973). The reduced evenness without horse grazing suggests that this had occurred to some extent. It might take longer for competitive exclusion to reduce the species number, or there may be sufficient grazing by wild ungulates in the "non-grazed" area to slow it. Studies of recovery of rough fescue grasslands (Willms et al. 1985; McLean and Tisdale 1972) show that, after several decades of recovery, species number was not reduced. However, in the longer term, Festuca campestris dominates to the exclusion of most other species (McLean and Tisdale 1972).

We found an increase in the Shannon-Wiener index with grazing, as shown by Bai et al. (2001) in Saskatchewan. Also similar to Bai et al., we found no change in species richness with moderate grazing. The Simpson's index is less sensitive to the contribution of lessabundant species (DeJong 1975) and, thus, did not increase with grazing.

The results of this study correspond to those of many others (Trottier 1993; West 1993; McLaughlin and Mineau 1995) in suggesting some biodiversity benefits of moderate grazing. Studies of grazing effects at many sites throughout Alberta would determine whether grazing affects biodiversity in all grassland types. A study conducted in the mixed prairie (Willms et al. 2002) suggests that grazing does not always improve diversity.

\section{General observations}

The species of vascular plants that were much more abundant in grazed areas are known to increase with increased grazing pressure and are mostly not grasses. These species are likely those previously avoided by bison and currently avoided to some extent by feral horses. Both of these ungulates are grass specialists. Some of the plants that apparently increased with horse grazing are toxic to horses (e.g., Oxytropis sericea and Toxicoscordion venenosum var. venenosum; Majak et al. 2008) and were possibly avoided for this reason. Allowing only moderate grazing by horses may also be beneficial to the horses as they may avoid toxic plants while alternatives are available.
Both the area grazed by horses and the area free of horses were significant in terms of overall biodiversity, with different species present and different abundance values of shared species and high biodiversity values according to different indexes. The grazed area favoured wildflowers that serve pollinators including numerous bees and butterflies (most of the forbs listed in Table 1). The Greenish Blue butterfly (Plebejus saepiolus amica [W. H. Edwards, 1863]; Figure 2) was abundant in the grazed area, with up to 10 in view at any one time, but entirely absent from the non-grazed area. A population of Speckle-winged Rangeland Grasshoppers (Arphia conspersa Scudder, 1875), which prefer areas with bare soil (P. M. C. personal observation), was present in the grazed area but entirely absent from the adjacent non-grazed area. The dominance of clumped grasses in the horse-free area provided structural cover for nesting birds such as Vesper Sparrows (Pooecetes gramineus) that were absent in the grazed area. Other studies have shown that below-ground arthropods, scavenging arthropods, and grasshoppers increase with grazing (Laycock 1994) and that birds are variously adapted to the extent of the grazing (Knopf 1996). The differences in biodiversity between the two sections may be much greater for other groups than for vascular plants, further supporting the high biodiversity value of the presence of both grazing regimes.

\section{Management implications}

Based on studies of recovery from grazing in rough fescue communities (Willms et al 1985; McLean and Tisdale 1972), the non-grazed area is likely at a midseral stage. There may be a number of distinct biodiversity-rich intermediate stages of succession in foothills prairies based on different levels of grazing pressure and other factors. Biodiversity was not necessarily greatest at the apparent intermediate level of disturbance, as might be expected (Bai et al. 2001; Vujnovic et al. 2002). However, succession and disturbance levels may not provide the most informative view of prairies.

In pre-settlement times, prairies were likely a shifting mosaic of heterogeneous patches where fire and grazing played major roles, along with periodic drought (Fuhlendorf and Engle 2004). Other important factors affecting diversity may have been spatial and temporal variation in movements of wandering bison herds, and fluctuations in numbers of ungulate predators, as well as variation in their distributions. For example, bison traces would have been heavily grazed, but areas where predator risk was high would not have been grazed. Drought and fire would have influenced both of these factors. In the case of our study site, biodiversity was increased by the creation of two patches with different grazing regimes. An improvement in management would involve changing the patches over space and time by applying different ecological situations, especially using fire as well as grazing, as suggested by Fuhlendorf and Engle (2004). With the loss of free- 


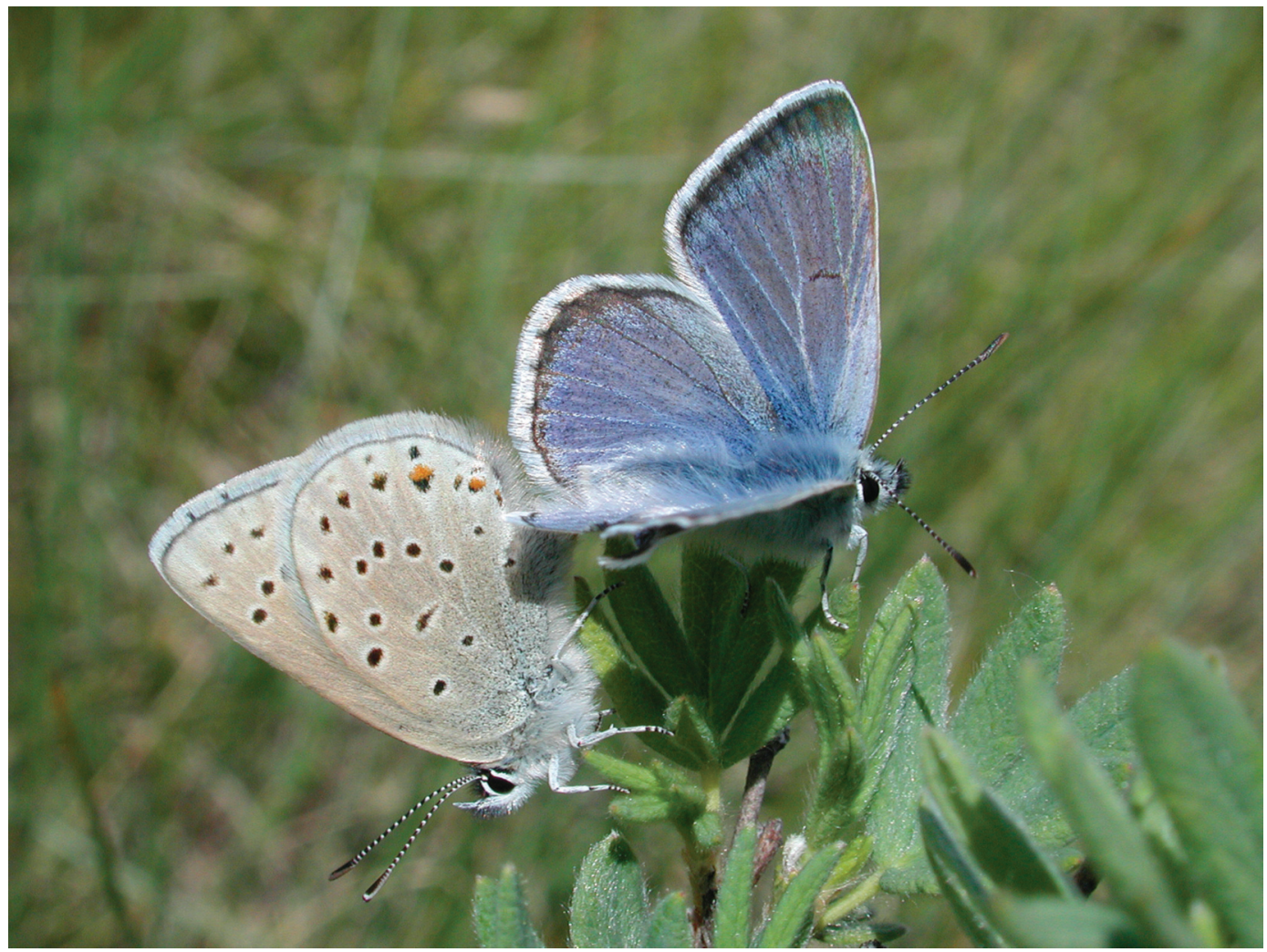

FIGURE 2. The Greenish Blue (Plebejus saepiolus amica (W.H. Edwards, 1863) was an abundant visitor to flowers of Oxytropis spp., which were much more abundant in the area of prairie subject to moderate grazing by feral Horses (Equus ferus caballus) than in an adjacent grazed area in northern Kananaskis Country, Alberta. Photo by Paul M. Catling.

ranging bison and the patch dynamics on which prairie diversity is based, the use of an increasing number of feral horses to achieve various levels of grazing is a potentially useful management tool that deserves widespread but well-planned application. Grazing by horses in foothills prairies at moderate to light levels can be beneficial in terms of biodiversity.

\section{Acknowledgements}

Bonnie Smith and C. C. Chinnappa of the University of Calgary Herbarium provided invaluable logistical support. Bow Valley Provincial Park warden, Rod Jaeger, and Chief Ecologist, Melanie Percy, provided information on the history of the study area and arranged for a permit to collect plant specimens. Gloria Cowley of Rafter Six guest ranch provided information on the history of the area west of the Kananaskis River.

Documents Cited (marked * in the text)

Brouillet, L., F. Coursol, S.J. Meades, M. Favreau, M. Anions, P. Bélisle, and P. Desmet. 2010+. VASCAN, the
Database of Vascular Plants of Canada. Accessed 28 August 2014. http://data.canadensys.net/vascan/

Kartesz, J. T., and C. A. Meacham. 1999. Synthesis of the North American Flora, Version 1.0 North Carolina Botanical Garden, Chapel Hill, North Carolina, USA

SAS Institute, Inc. 2003. Statistical analysis system. Version 9.1, Copyright (C) 2003 [computer program]. SAS Institute Inc. SAS and all other SAS Institute Inc. product or service names are registered trademarks or trademarks of SAS Institute Inc., Cary, North Carolina, USA.).

McCune, B., and J. B. Grace. 2002. Analysis of Ecological Communities. MjM Software, Gleneden Beach, Oregon, USA.

Wallis, C., and C. Wershler. 1972. Ecological survey of Bow Valley Provincial Park, vol. 1 and 2. Provincial Parks Planning Department, Alberta Parks Division, Edmonton, Alberta, Canada.

Westar Inc. 2003. Horse industry profile and economic impact survey for Horse Industry Association of Alberta. Weststar Inc., Edmonton, Alberta, Canada. Accessed 28 September 2014. http//www.albertahorseindustry.ca/econo micsurvey/complete profile.pdf

Williams, J. 1988. Vegetation inventory, Bow Valley Provincial Park, Alberta. Recreation and Parks, Operations Branch, Kananaskis Country, Canmore, Alberta. 


\section{Literature Cited}

Bai, Y., Z. Abouguendia, and R. F. Redmann. 2001. Relationship between plant species diversity and grassland condition. Journal of Range Management 54: 177-183.

Beever, E. A., and P. F. Brussard. 2000. Examining ecological consequences of feral horse grazing using exclosures. Western North American Naturalist 60: 236-254.

Beever, E. A., R. J. Tausch, and W. E. Thogmartin. 2008. Multi-scale responses of vegetation to removal of horse grazing from Great Basin (USA) mountain ranges. Plant Ecology 196: 163-184.

Bowden, W. M. 1960. Chromosome numbers and taxonomic notes on northern grasses. II. Tribe Festuceae. Canadian Journal of Botany 38: 117-131.

DeJong, T. M. 1975. A comparison of three diversity indices based on their components of richness and evenness. Oikos, 26: $222-227$.

Detling, J. K. 1998. Mammalian herbivores: ecosystem-level effects in two grassland national parks. Wildlife Society Bulletin 26: 438-448.

Fleischner, T. L. 1994. Ecological costs of herbivory grazing in western North America. Conservation Biology 8: 629644.

Flora of North America Editorial Committee (editors). 1993+. Flora of North America North of Mexico. 16+ vols. New York and Oxford. Accessed 28 September 2014. http://www.efloras.org/flora page.aspx?flora_id=1

Fuhlendorf, S. D., and D. M. Engle. 2004. Application of the fire-grazing interaction to restore a shifting mosaic on tallgrass prairie. Journal of Applied Ecology 41(4): 604-614.

Greenlee, G. M. 1974. Soil survey of Bow Valley Provincial Park and adjacent Kananaskis area and interpretation for recreational use. Soils Division, Alberta Research Council, Edmonton, Alberta, Canada. 76 pages +2 maps.

Grime, J. P. 1973. Competitive exclusion in herbaceous vegetation. Nature 242: 344-347.

Knopf, F. L. 1996. Perspectives on grazing nongame bird habitats. Pages 51-58 in Rangeland Wildlife. Edited by P. R. Krausman. Society for Range Management, Denver, Colorado, USA.

Kuijt, J. 1982. A flora of Waterton Lakes National Park. University of Alberta Press, Edmonton, Alberta, Canada.

Hallworth, B. and C. C. Chinnappa. 1997. Plants of Kananaskis Country in the Rocky Mountains of Alberta. University of Calgary Press, Calgary, Alberta, Canada.

Lauenroth, W. K., D. G. Milchunas, J. L. Dodd, R. H. Hart, R. K. Heitschmidt, and L. R. Rittenhouse. 1994. Effects of grazing on ecosystems of the Great Plains. Pages 69-100 in Ecological Implications of Livestock Herbivory in the West. Edited by M. Vavra, W. A. Laycock and R. D. Pieper. Society for Range Management, Denver, Colorado, USA.

Laycock, W. A. 1994. Implications of grazing vs. no grazing on todays rangelands. Pages 250-280 in Ecological Implications of Livestock Herbivory in the West. Edited by M. Vavra, W. A. Laycock and R. D. Pieper. Society for Range Management, Denver, Colorado, USA.

Majak, W., B. M. Brooke, and R. T. Ogilvie. 2008. Stockpoisoning Plants of Western Canada. Kamloops Range Research Unit, Agriculture and Agri-Food Canada, Kamloops, British Columbia, Canada.

McLaughlin, A., and P. Mineau. 1995. The impact of agricultural practices on biodiversity. Agricultue, Ecosystems and Environment 55: 201-212.
McLean, A., and E. W. Tisdale. 1972. Recovery rate of depleted range sites under protection from grazing. Journal of Range Management 25: 178-184.

Ollf, H., and M. E. Ritchie. 1998. Effects of herbivores on grassland plant diversity. Trends in Ecology and Evolution 13: 261-265.

Packer, J. G. 1994. Flora of Alberta, second edition. University of Toronto Press, Toronto, Ontario, Canada.

Pavlick, L. E., and Looman, J. 1984. Taxonomy and nomenclature of rough fescues, Festuca altaica, F. campestris ( $F$. scabrella var. major), and $F$. hallii, in Canada and the adjacent part of the United States. Canandian Journal of Botany 62: 1739-1749.

Pinel, H. 1985. Plant species list for Bow Valley Provincial Park, Exshaw, Alberta. Alberta Parks, Edmonton, Alberta, Canada.

Rutherford, R. L. 1927. Geology along the Bow River between Cochrane and Kannanaskis, Alberta. Research Council of Alberta report 17. Research Council of Alberta, Geological Survey Division, Edmonton, Alberta, Canada.

Tannas, C. 2003a. Common Plants of the Western Rangelands, volume 1, Grasses and Grass-like Species. Alberta Agriculture, Food, and Rural Development, Edmonton, Alberta, Canada.

Tannas, C. 2003b. Common Plants of the Western Rangelands, volume 2, Trees and Shrubs. Alberta Agriculture, Food, and Rural Development, Edmonton, Alberta, Canada.

Tannas, C. 2004. Common Plants of the Western Rangelands, volume 3, Forbs. Alberta Agriculture, Food, and Rural Development, Edmonton, Alberta, Canada.

Trottier, G. 1993. Some thoughts on agriculture-prairie conservation integration. Pages 10-11 in Proceedings of the Third Prairie Conservation and Endangered Species Workshop. Natural history occassional paper. Edited by G. L. Holroyd, H. L. Dickson, M. Regnier, and H. C. Smith. Curatorial Section Provincial Museum of Alberta, Edmonton, Alberta, Canada.

Trottier, G. 2002. A landowner's Guide: Conservation of Canadian Prairie Grasslands. Canadian Wildlife Service, Environment Canada, Edmonton, Alberta, Canada.

Vujnovic, K. 1998. Small-scale plant species composition and diversity in relation to environmental and disturbance factors in Fescue. M.Sc. thesis, University of Alberta, Edmonton, Alberta, Canada.

Vujnovic, K., R. W. Wein, and M. R. T. Dale. 2002. Predicting plant species diversity in response to disturbance magnitude in grassland remnants of central Alberta. Canadian Journal of Botany 80: 504-511.

West, N. E. 1993. Biodiversity of rangelands. Journal of Range Management 46: 2-13.

Willms, W. D., B. W. Adams, and J. F. Dormaar. 1996. Seasonal changes of herbage biomass on the fescue prairie. Journal of Range Management 49: 100-104.

Willms, W. D., J. F. Dormaar, and G. B. Schaalje. 1988. Stability of grazed patches on rough fescue grasslands. Journal of Range Management 41: 503-508.

Willms, W. D., J. F. Dormaar, B. W. Adams, and H. E. Douwes. 2002. Response of the mixed prairie to protection from grazing. Journal of Range Management 55: 210-216.

Willms, W. D., S. Smoliak, and J. F. Dormaar. 1985. Effects of stocking rate on Rough Fescue grassland vegetation. Journal of Range Management 38: 220-225.

Received 21 January 2014

Accepted 8 May 2014 
APPENDIX 1. Total list of species recorded (including quadrats) in a prairie glade in northern Kananaskis Country, Alberta, with scientific name, common name, some synonyms, and accession number of specimens preserved in the National Collection of Vascular Plants, Agriculture and Agri-Food Canada.

\begin{tabular}{|c|c|c|}
\hline Scientific name & Common name & Accession number \\
\hline Achillea millefolium $\mathrm{L}$. & Common Yarrow & 843223 \\
\hline Achnatherum richardsonii (Link) Barkworth & Richardson's Needlegrass & 843236,843298 \\
\hline Agoseris glauca (Pursh) Rafinesque & Pale Goat-chicory & 843264 \\
\hline Allium cernuum Roth & Nodding Onion & 843301 \\
\hline Androsace chamaejasme Wulfén ex Host & Sweet-flowered Rock Jasmine & 843271 \\
\hline Androsace septentrionalis L. & Pygmyflower Rock jasmine & 843228 \\
\hline Anemone multifida Poiret & Red Windflower & 843221 \\
\hline $\begin{array}{l}\text { Anemone patens L. var. multifida Pritzel (syn. } \\
\text { Pulsatilla patens) }\end{array}$ & Prairie Crocus & 843267 \\
\hline Antennaria anaphaloides Rydberg & Tall Pussytoes & 843296 \\
\hline Antennaria parvifolia Nuttall & Little-leaved Pussytoes & 843319 \\
\hline Anticlea elegans (Pursh) Rydberg (syn. Zigadenus elegans) & Mountain Death Camas & 843320 \\
\hline $\begin{array}{l}\text { Arabis hirsuta M. Hopkins var. pycnocarpa } \\
\quad \text { (M. Hopkins) Rollins }\end{array}$ & Hairy Rockcress & 843250 \\
\hline Arctostaphylos uva-ursi (L.) Sprengel & Red Bearberry & \\
\hline Artemisia campestris L. & Pacific Wormwood & 843315 \\
\hline Artemisia frigida Willdenow & Prairie Sagebrush & 843316 \\
\hline Astragalus agrestis Douglas ex G. Don & Cock's-head & 843278 \\
\hline Astragalus australis (L.) Lamarck & Indian Milk-vetch & 843286,843298 \\
\hline $\begin{array}{l}\text { Astragalus laxmanii Jacquin var. robustior } \\
\text { (Hooker) Barneby and S.L. Welsh }\end{array}$ & Ascending Purple Milk-vetch & \\
\hline * Bromus inermis Leysser & Smooth Brome & \\
\hline Campanula rotundifolia $\mathrm{L}$. & Round-leaf Harebell & \\
\hline Carex duriuscula C. A. Meyer & Spikerush Sedge & 843252 \\
\hline Carex filifolia Nuttall & Thread-leaved Sedge & 843238,843275 \\
\hline Carex obtusata Liljeblad & Blunt Sedge & 843277 \\
\hline Carex richardsonii $\mathrm{R}$. Brown & Richardson's Sedge & 843302 \\
\hline Carex rossii Boott & Ross' Sedge & 843240,843260 \\
\hline Carex scirpoidea Michaux & Canadian Single-spike Sedge & 843272 \\
\hline Castilleja rhexifolia Rydberg & Rosy Indian-paintbrush & 843297 \\
\hline Cerastium arvense $\mathrm{L}$. & Field Mouse-ear Chickweed & 843262 \\
\hline $\begin{array}{l}\text { Comandra umbellata (L.) Nuttall ssp. pallida } \\
\text { (A. de Candolle) Piehl }\end{array}$ & Pale Bastard-toadflax & 843279 \\
\hline Crepis runcinata (E. James) Torrey \& A. Gray & Fiddle-leaved Hawksbeard & 843306 \\
\hline $\begin{array}{l}\text { Dactylorhiza viridis (L.) R.M. Bateman, Pridgeon \& } \\
\text { M.W. Chase (syn. Coeloglossum viride var. virescens) }\end{array}$ & Frog Orchid & 843314 \\
\hline $\begin{array}{l}\text { Dasiphora fruticosa (L.) Rydberg (syn. Dasiphora } \\
\quad \text { fruticosa ssp. floribunda (Pursh) Kartesz) }\end{array}$ & Shrubby Cinquefoil & 843239 \\
\hline Delphinium bicolor Nuttall & Flathead Larkspur & 843219 \\
\hline Draba cana Rydberg (syn. Draba breweri var. cana) & Cushion Whitlowgrass & 843292,843318 \\
\hline Draba nemorosa L. & Woodland Whitlowgrass & 843253,843323 \\
\hline Elymus glaucus Buckley & Blue Wildrye & 843237 \\
\hline $\begin{array}{l}\text { Elymus lanceolatus (Scribner \& J.G. Smith) } \\
\text { Gould ssp. lanceolatus }\end{array}$ & Streamside Wildrye & 843243 \\
\hline Erigeron caespitosus Nuttall & Tufted Fleabane & 843224 \\
\hline $\begin{array}{l}\text { Erigeron glabellus Nuttall var. glabellus } \\
\text { (syn. Erigeron asper Nuttall) }\end{array}$ & Rough Fleabane & 843220 \\
\hline Eriogonum flavum Nuttall & Alpine Golden Wild Buckwheat & 843300 \\
\hline Erysimum inconspicuum (S. Watson) MacMillan & Shy Wallflower & 843258 \\
\hline Festuca campestris Rydberg & Northern Rough Fescue & 843231,843273 \\
\hline *Festuca cf. ovina L. & Sheep Fescue & 843291,843295 \\
\hline $\begin{array}{l}\text { Festuca saximontana Rydberg var. purpusiana } \\
\text { (Saint-Yves) Frederiksen \& Pavlick }\end{array}$ & Rocky Mountain Fescue & $843241,843313,843324$ \\
\hline Fragaria virginiana Miller & Wild Strawberry & \\
\hline Gaillardia aristata Pursh & Great Blanketflower & 843288,843310 \\
\hline Galium boreale L. & Northern Bedstraw & \\
\hline Geum triflorum Pursh & Prairie Smoke & 843255 \\
\hline $\begin{array}{l}\text { Hedysarum alpinum L. (syn Hedysarum alpinum ssp. } \\
\text { americanum (Michaux ex Pursh) B. Fedtschenko) }\end{array}$ & Alpine Sweet-vetch & $843225,843268,843304$ \\
\hline Gentianella amarella (L.) Börner & Autumn Dwarf Gentian & 843256 \\
\hline
\end{tabular}


APPENDIX 1. (continued)

\begin{tabular}{|c|c|c|}
\hline Scientific name & Common name & Accession number \\
\hline Hedysarum boreale Nuttall & Northern Hedysarum & \\
\hline Hedysarum sulphurescens Rydberg & Yellow Sweet-vetch & 843227 \\
\hline Helictotrichon hookeri (Scribner) Holub & Hooker's Alpine Oatgrass & $\begin{array}{l}843230,843232,843299, \\
843311,843321\end{array}$ \\
\hline Heuchera cylindrica Douglas & Poker Alumroot & 843274 \\
\hline Juniperus communis var. depressa Pursh & Common Juniper & \\
\hline Juniperus horizontalis Moench & Creeping Juniper & \\
\hline Koeleria macrantha (Ledebour) Schultes & Junegrass & 843234,843261 \\
\hline *Lappula squarrosa (Retzius) Dumortier & Bristly Sheepburr & 843218 \\
\hline $\begin{array}{l}\text { Lilium philadelphicum L. (syn. Lilium philadelphicum } \\
\quad \text { var. andinum (Nuttall) Ker Gawler) }\end{array}$ & Wood Lily & 843293 \\
\hline Lithospermum ruderale Douglas ex Lehmann & Columbia Puccoon & 843308 \\
\hline Maianthemum stellatum (L.) Link & Starry False Solomon's Seal & \\
\hline Muhlenbergia richardsonis (Trinius) Rydberg & Mat Muhly & 843354 \\
\hline $\begin{array}{l}\text { Oxytropis borealis de Candolle var. viscida } \\
\text { (Nuttall) S.L. Welsh }\end{array}$ & Boreal Locoweed & 843305 \\
\hline $\begin{array}{l}\text { Oxytropis deflexa (Pallas) de Candolle ssp. sericea } \\
\text { (Torrey \& A. Gray) Cody (syn. Oxytropis deflexa } \\
\text { var. sericea Torrey \& A. Gray) }\end{array}$ & White Pendant-pod Locoweed & 843222,843247 \\
\hline Oxytropis monticola A. Gray & Yellow-flower Locoweed & $\begin{array}{l}843249,843276,843282, \\
843283\end{array}$ \\
\hline Oxytropis sericea Nuttall & Rocky Mountain Locoweed & 843248,843280 \\
\hline Oxytropis splendens Douglas ex Hooker & Whorled Locoweed & \\
\hline Packera cana (Hooker) W.A Weber \& Á. Löve & Silvery Groundsel & 843287 \\
\hline Penstemon confertus Douglas ex Lindley & Lesser Yellow Beardtongue & 843294 \\
\hline *Phleum pratense L. & Common Timothy & \\
\hline Poa cusickii Vasey & Cusick's Bluegrass & 843254,843303 \\
\hline Poa pratensis L. & Kentucky Bluegrass & 843269 \\
\hline $\begin{array}{l}\text { Poa secunda J. Presl ssp. secunda (syn. Poa sandbergii } \\
\text { Vasey) }\end{array}$ & Sandberg's Bluegrass & $\begin{array}{l}843233,843235,843246, \\
843281\end{array}$ \\
\hline Poa sp. & Bluegrass (unknown) & 843322 \\
\hline Populus tremuloides Michaux & Trembling Aspen & \\
\hline Potentilla concinna Richardson & Red Cinquefoil & 843244 \\
\hline Potentilla pensylvanica $\mathrm{L}$. & Pennsylvania Cinquefoil & 843245 \\
\hline $\begin{array}{l}\text { Primula conjugens (Greene) A.R. Mast \& Reveal var. } \\
\text { conjugens (syn. Dodecatheon conjugens) }\end{array}$ & Bonneville Shootingstar & 843290 \\
\hline $\begin{array}{l}\text { Primula pauciflora (Greene) A.R. Mast \& Reveal var. } \\
\text { pauciflora (syn. Dodecatheon pulchellum) }\end{array}$ & Dark-throat Shootingstar & 843298 \\
\hline Rhinanthus minor L. & Little Yellow Rattle & \\
\hline $\begin{array}{l}\text { Sabulina rubella }(\text { Wahlenberg) Dillenberger \& Kadereit } \\
\quad \text { (syn. Minuartia rubella) }\end{array}$ & Boreal Stitchwort & 843259 \\
\hline Selaginella densa Rydberg & Dense Spikemoss & 843242 \\
\hline Silene parryi (S. Watson) C.L. Hitchcock \& Maguire & Parry's Catchfly & 843317 \\
\hline Sisyrinchium montanum Greene & Strict Blue-eyed Grass & 843251 \\
\hline Sisyrinchium septentrionale E.P. Bicknell & Northern Blue-eyed Grass & 843257 \\
\hline Solidago simplex ssp. & Mt. Albert Goldenrod & \\
\hline Symphoricarpos sp. & Snowberry & 843309 \\
\hline $\begin{array}{l}\text { Symphyotrichum laeve (L.) A. Löve \& D. Löve } \\
\text { var. geyeri (A. Gray) G.L. Nesom }\end{array}$ & Smooth Blue Aster & \\
\hline *Taraxacum officinale F.W. Wiggers & Common Dandelion & 843226 \\
\hline Thalictrum venulosum Trelease & Veiny-leaved Meadow-rue & 843263 \\
\hline $\begin{array}{l}\text { Toxicoscordion venenosum (S. Watson) } \\
\text { Rydberg var. venensoum }\end{array}$ & Meadow Death Camas & 843265,843312 \\
\hline Vicia americana Muhlenberg ex Willdenow & American Purple Vetch & 843229 \\
\hline Viola canadensis L., & Canada Violet & \\
\hline Zizia aptera (A. Gray) Fernald & Heart-leaved Alexanders & 843266 \\
\hline
\end{tabular}

*Non-native species. 